Adrian Zabielski

Uniwersytet Mikołaja Kopernika, Toruń

adrian.zabielski@gmail.com

\title{
Nakręcane światy. Twórczość Paolo Bacigalupiego w kontekście wybranych elementów kapitalistycznego systemu-świata
}

DOI: http://dx.doi.org/10.12775/RF.2018.017

\section{Wprowadzenie}

Tematem artykułu jest studium przypadku - wpisanie twórczości Paolo Bacigalupiego w kontekst nauk społecznych. To praca na styku beletrystyki i literatury akademickiej, która, jak sądzę, uwydatni wartość dzieł tego autora $\mathrm{w}$ opisywaniu nie tylko współczesnego świata, ale także w wyznaczaniu perspektyw dotyczących możliwej przyszłości.

Twórczość Paolo Bacigalupiego wpisuje się w gatunek literatury science-fiction zwany biopunkiem. W światach przedstawionych jego powieści i opowiadań kluczową rolę odgrywają biotechnologie, wyeksponowane są efekty zmian klimatycznych i systemowych. W dziełach Bacigalupiego można dostrzec polityczną wrażliwość, ujawniającą się w celnym, metaforycznym ujęciu problemów współczesnego świata. Ekstrapolując w daleką przyszłość pewne zagadnienia, na których obecnie koncentrują się nauki społeczne, Bacigalupi tworzy kompleksowe, wielowymiarowe dystopie. Przewaga tych dzieł nad pracami naukowymi polega na tym, że ich powstawanie nie jest ograniczane przez reżim metodologiczny, dzięki czemu aspekt problemowy i prewidystyczny może wykroczyć poza obszar znajdujący się w zasięgu nauk społecznych. Ze względu na fabularny charakter utwory Bacigalupiego są także bardziej obrazowe i łatwiejsze w odbiorze dla osób funkcjonujących 
poza akademia, stanowiąc cenne źródło popularyzacji pewnych wizji świata. Przyjmując takie założenia, w dalszej części referatu skoncentruję się na powieści Nakręcana dziewczyna oraz zbiorze opowiadań Pompa numer sześć ${ }^{1}$.

\section{Bacigalupi a kapitalistyczny system-świat}

Immanuel Wallerstein $\mathrm{w}$ swoich pracach zwrócił uwagę na kwestię końca kapitalistycznego systemu-świata, oznaczającego także zmianę centro-peryferyjnego układu globalnych zależności². Według niego współcześnie znajdujemy się u kresu globalnej, kapitalistycznej formacji systemowej, która dominuje na świecie od XV wieku. Nie posiadamy przy tym żadnej pewnej wiedzy na temat przyszłego kształtu świata. Obszarami stabilizacji przestały być nauka i technika, które niosły optymistyczną wizję przyszłości. Mrzonką okazała się modernistyczna idea nieproblematycznego i linearnego rozwoju tych dziedzin ludzkiej działalności, będąca kontynuacją oświeceniowej idei wiecznego postępu. Znaleźliśmy się w sytuacji, w której dominuje zwątpienie, niepewność jutra i dziejowy pesymizm. Ten ostatni związany jest z upadkiem komunizmu i kryzysem kapitalizmu, które w dialektycznej walce kształtowały świat w XX wieku. Współczesność to czas bifurkacji, czyli wyboru przyszłej formacji systemowej. Będzie to okres gwałtownych, chaotycznych przemian, skutkujących aktami przemocy, zwiększoną mobilnością społeczną między krajami rdzenia i peryferiów oraz, być może, dezintegracją państwa narodowego jako gwaranta bezpieczeństwa.

Według Wallersteina na kształt przyszłego systemu-świata będą miały wpływ cztery zjawiska, które jednocześnie ujawniają słabość kapitalistycznej idei nieograniczonego wzrostu: deruralizacja, kryzys ekologiczny, powszechna demokratyzacja oraz osłabienie znaczenia państwa. Związane będą one z coraz silniejszą polaryzacją społeczeństwa, zarówno na poziomie indywidualnym, jak i globalnym. Na znaczeniu zyskają kraje Azji Wschodniej, takie jak Chiny, Tajwan, Korea Południowa i Japonia, do których przenoszona jest produkcja przemysłowa ze

1 P. Bacigalupi, Nakręcana dziewczyna. Pompa numer sześć i inne opowiadania, przeł. W. M. Próchniewicz, Wydawnictwo MAG, Warszawa 2011.

2 I. Wallerstein, Koniec świata jaki znamy, przeł. M. Bilewicz, A. W. Jelonek, K. Tyszka, Wydawnictwo Naukowe Scholar, Warszawa 2004. W temacie koncepcji systemów-światów tego autora zob. też: I. Wallerstein, Analiza systemów-światów. Wprowadzenie, przeł. K. Gawlicz i M. Starnawski, Wydawnictwo Akademickie Dialog, Warszawa 2007; idem, Nowoczesny system-świat, przeł. A. Ostolski, w: Wspótczesne teorie socjologiczne, red. A. Jasińska-Kania, L. Nijakowski, J. Szacki, M. Ziółkowski, Wydawnictwo Naukowe Scholar, Warszawa 2006; idem, Utopistyka. Alternatywy historyczne dla XXI wieku, przeł. I. Czyż, Oficyna Trojka, Poznań 2008. 
Stanów Zjednoczonych i Europy. W kontekście teorii Wallersteina trend ten sugeruje, że kraje Azjatyckie odegrają istotną rolę w kształtowaniu nadchodzącego systemu-świata, chociaż biorąc pod uwagę niepewność towarzyszącą bifurkacji nie wiadomo, jaka to będzie rola.

Paolo Bacigalupi ujmuje kwestię systemowej bifurkacji w metaforyce Ekspansji i Zapaści, opisując nie tylko samo zjawisko, ale także możliwe jego skutki. Jeśli wierzyć opowieściom postaci występujących w Nakręcanej dziewczynie, Ekspansja była globalnym „złotym wiekiem” - okresem, w którym kapitalizm przeżywał swój rozkwit. Dzięki totalnemu otwarciu rynków i granic państwowych ludzkość się bogaciła, a łańcuchy towarowe oplatały cały świat. Ten szczytowy moment w ludzkich dziejach nie byłby możliwy bez eksploatacji paliw kopalnych. W związku z gwałtownym rozwojem nauki i techniki zwiększyło się zapotrzebowanie na energię. Globalne zasoby węglowodorów błyskawicznie się wyczerpywały. Konsekwencją tego podejścia było ekologiczne wydarzenie zwane Zapaścią, które rozwiało utopijną wizję nieograniczonego wzrostu. Gdy wyczerpały się ropa i węgiel, stanęły elektrownie i fabryki, na polach i drogach ugrzęzły bezużyteczne maszyny, globalny transport zamarł. Na całym świecie rozszalały się śmiertelne choroby, takie jak rdza pęcherzowa i cibiskoza, oraz zmutowane szkodniki, jak na przykład niewidzialne koty. Zapanował globalny głód. Państwa przyjęły politykę izolacjonistyczna, ograniczając przepływ ludzi i towarów. Pojawiła się możliwość wyjścia poza kapitalistyczny system-świat, lecz dominację przejęły międzynarodowe korporacje, które podporządkowały sobie mieszkańców i rządy upadających państw. Bacigalupi tak opisuje sytuację polityczną świata przedstawionego:

Żyjemy, choć upadły całe państwa i królestwa. Choć Malezja to mordercza dżungla. Choć Kowloon jest pod wodą. Choć Chiny są podzielone, Wietnam upadł, a Birma to tylko głód. Nie ma już amerykańskiego imperium. Unia Europejczyków rozpadła się i podzieliła. A my przetrwaliśmy, nawet rośniemy. Królestwo żyje ${ }^{3}$.

Dystopijny świat Nakręcanej dziewczyny realizuje jedną ze ścieżek, którą Wallerstein opisał jako możliwy efekt obecnie przebiegającej przemiany systemowej. Wiąże się ona z państwowym izolacjonizmem, autorytarnymi rządami lokalnymi i korporacyjną refeudalizacją. Tajlandia przyszłości z Nakręcanej dziewczyny zachowała względną niezależność od korporacyjnej polityki dzięki zamknięciu granic. Głową państwa jest monarchini, mała królowa. Na straży porządku stoją dwa ministerstwa: Handlu i Środowiska, które w czasach Ekspansji pełniły marginalne role,

3 P. Bacigalupi, Nakręcana dziewczyna. Pompa numer sześć i inne opowiadania, przeł. W. M. Próchniewicz, Wydawnictwo MAG, Warszawa 2011, s. 446. 
lecz ze względu na zakres obowiązków znacznie zyskały na znaczeniu, gdy system się zawalił. Ministerstwo Środowiska, ze swoimi tajnymi laboratoriami, zajęło się likwidowaniem ognisk chorobowych, kontrolą żywności i dbaniem o przestrzeganie legalności źródeł metanu, który po Zapaści zastąpił węgiel i ropę w wielu sferach życia. Ministerstwo Handlu zaś zadbało o szczelność granic, kontrolę migracji oraz negocjacje $\mathrm{z}$ korporacjami.

\section{Bacigalupi a technokratyczna refeudalizacja}

Pomimo izolacjonizmu Tajlandia z Nakręcanej dziewczyny umożliwia farangom, czyli białym przybyszom, otwieranie fabryk na swoim terytorium. Przykładem takiego zakładu jest fabryka sprężyn, zarządzana przez jednego z głównych bohaterów powieści - Andersona. Anderson jest w rzeczywistości agentem firmy kalorycznej AgriGen. To ekonomiczny zabójca na usługach korporacji. Jego głównym zadaniem jest stworzenie politycznego gruntu pod zamach stanu i odnalezienie tajskiego banku nasion. Mając dostęp do tego banku, laboratoria AgriGenu zyskałyby możliwość różnicowania materiału genetycznego swoich roślin uprawnych. To bezcenne źródło genów pozwala Tajlandii na względną niezależność od polityki korporacyjnej, a lokalni rolnicy mogą dzięki niemu nabywać reglamentowane przez państwo, różnorodne nasiona. Chociaż autorytarna władza tego kraju stawia opór całkowitej liberalizacji gospodarki i otwarciu granic firmom kalorycznym, to w kuluarach ministerstw mówi się już o stopniowym zbliżaniu się Drugiej Ekspansji.

W opowiadaniu Kaloriarz, którego akcja toczy się w tym samym świecie co Nakręcana dziewczyna, bohater imieniem Lalji wspomina bezskuteczny trud uzyskania plonów z genetycznie modyfikowanych ziaren:

[Lalji] przypomniał sobie siew. Kucał z ojcem w pustynnym skwarze, wśród żółtego pyłu, zakopując zachomikowane nasiona, oszczędzone, choć można było je zjeść, zachowane, choć mogły sprawić, żeby Gita przytyła i nadawała się do małżeństwa. Ojciec, uśmiechnięty, mówił: - Te ziarna urodzą setki nowych i wtedy wszyscy będziemy porządnie jeść. [...] wreszcie ojciec pokręcił głową i powiedział, że wszystko na nic. [Lalji] jednak wciąż miał nadzieję, aż wreszcie poszedł na pole i wykopał je jedno po drugim - już były zepsute, małe zgniłe trupki w jego dłoni. [...] Wtedy pierwszy raz naprawdę posmakował PurCala ${ }^{4}$.

4 Ibidem, s. 121. 
Nieposiadający specjalistycznej wiedzy i dostępu do laboratoriów rolnicy małorolni systemowo przegrali w tym świecie rywalizację z technokratycznymi, międzynarodowymi molochami, produkującymi genetycznie modyfikowane rośliny, takie jak soja SoyPro, ryż U-Tex czy pszenica TotalNutrient.

Nietrudno dostrzec $\mathrm{w}$ takiej konstrukcji świata przedstawionego analogie do działalności współczesnych korporacji żywnościowych, takich jak Monsanto-Bayer, Nestle, Aventis, Pioneer czy Sygenta, które poprzez patentowanie ziaren i pestycydów oraz szeroko zakrojone kampanie promocyjne dążą do przejęcia całkowitej kontroli nad rynkiem produkcji żywności. Technokratyczna refeudalizacja jest w prostej linii efektem dominacji kapitalistycznego systemu-świata, a akumulacja władzy i środków w oligopolach jest, według Immanuela Wallersteina, zjawiskiem symptomatycznym dla obecnej bifurkacji ${ }^{5}$. W krajach rolniczych, jak Indie czy Bangladesz, losy milionów ludzi zależą od globalnej polityki prowadzonej przez koncerny żywnościowe. Walden Bello pisze w Wojnach żywnościowych o tym, że współcześnie kapitalizm stał się główną formą organizacji rolnictwa, globalnie niemal całkowicie wypierając tradycję chłopską . W neoliberalnym modelu gospodarki dąży się do "odchłopienia" - wyeliminowania pewnych tradycyjnych sposobów kształtowania tożsamości i społeczności skoncentrowanych wokół pracy na roli, ale uznawanych za nierentowne. Efektem tego jest deruralizacja, kapitalistyczna kolektywizacja rolnictwa i tworzenie gigantycznych farm, nastawionych na zysk, produkujących żywność na skalę przemysłową. Polityka maksymalizacji dochodów uprawiana przez przemysł żywnościowy we współpracy z państwami jest źródłem globalnego kryzysu żywnościowego. $Z$ tego względu Bello ostrożnie podchodzi także do kwestii GMO, istnieje bowiem ryzyko, że ze względu na dominującą pozycję korporacji sytuacja może wymknać się spod kontroli. Produkcja żywności nie jest jednak branżą odosobnioną. Jak zwraca uwagę Jean Ziegler w Imperium hańby, korporacje generalnie ignorują społeczne koszty swojej działalności w krajach peryferyjnych, akceptując takie praktyki, jak praca niewolnicza i przymusowa oraz zatrudnianie dzieci, ponosząc odpowiedzialność tylko wtedy, gdy uwagę na to zwróci społeczność międzynarodowa7. Ujęciem problemu niewolnictwa w Nakręcanej dziewczynie jest między innymi wątek Mai - tajskiej dziewczynki

5 I. Wallerstein, Koniec świata jaki znamy, przeł. M. Bilewicz, A. W. Jelonek, K. Tyszka, Wydawnictwo Naukowe Scholar, Warszawa, 2004, s. 62.

${ }_{6}$ W. Bello, Wojny żywnościowe, przeł. P. M. Bartolik, Instytut Wydawniczy Książka i Prasa, Warszawa 2011.

${ }^{7}$ J. Ziegler, Imperium hańby, przeł. E. Cylwik, Instytut Wydawniczy Książka i Prasa, Warszawa 2011. 
pracującej w fabryce sprężyn Andersona, a także innych zatrudnianych przez niego ludzi, wyzyskiwanych w ekstremalnych warunkach.

\section{Bacigalupi a kwestie ekologiczne}

Istotną oś konstrukcyjną światów przedstawionych dzieł Bacigalupiego stanowią wątki ekologiczne. W opowiadaniu Ludzie piasku i popiotu Ziemia to toksyczna pustynia zniszczona działalnością człowieka. Rzekami zamiast wody płyną chemikalia. Oceany to wielkie plamy ropy. Plaże pokryte są odpadami i drutem kolczastym, a niebo zasnuwają kłęby dymu. To środowisko tak zdewastowane, że tylko odpowiednio zmodyfikowane organizmy są $\mathrm{w}$ stanie $\mathrm{w}$ nim przetrwać. Zwykły pies, któremu udało się jakoś przeżyć w tym nieprzyjaznym świecie, wydaje się reliktem przeszłości, prehistorycznym stworem, skazanym na niechybną śmierć:

- Aż ciężko uwierzyć, że w ogóle udało nam się przeżyć na tyle długo, żeby z tego wyewoluować. Jeśli mu obetniesz łapę, wcale nie odrośnie. [...] Kruchy jak skała. Raz złamać i nie poskłada się z powrotem. [...] Łatwy do zabicia jak myśliwiec. Lisa i ja gapiliśmy się na psa, nasze prywatne okienko na prehistorię 8 .

W innym opowiadaniu, noszącym tytuł Łowca tamaryszków, Bacigalupi doprowadza do ekstremum faktycznie występujący problem kalifornijskich susz. Umieszcza go dodatkowo w kontekście społecznych rozwarstwień występujących w kapitalizmie: dostęp do wody jest reglamentowany, a stanową pustynię patroluje wojsko, Gwardia Narodowa i najemnicy pilnujący przestrzegania kwot wodnych. Zamknięci w miastach-twierdzach zamożni Amerykanie budują "słomkę" - gigantyczny rurociąg, który ma gromadzić i doprowadzać resztki wody do ich siedzib. Ci, których nie było stać na przeprowadzenie się do miast, muszą „kiwać system”, żeby przetrwać, tak jak tytułowy bohater opowiadania. Ostatecznie jednak nie ma ucieczki przed klimatycznym i społecznym kataklizmem:

Kiedy Kalifornia pierwsza ogłosiła roszczenia wodne, z początku nikt się nie przejął. Parę miasteczek zaczęło błagać o wodę. Paru przygłupiastych nowych z kiepskim prawem do wody przestało paść swoje konie i tyle. Parę lat później prysznice bardzo się skróciły. Jeszcze parę - zaczęli się kąpać raz w tygodniu, a potem - korzystać z wiader. Wtedy skończyły się żarty o upale i gorących kobietach. Problemem nie był tak naprawdę brak

8 P. Bacigalupi, Nakręcana dziewczyna. Pompa numer sześć i inne opowiadania, op. cit., s. 67. 
wody albo nadmierny upał. Problemem było to, że pięć i pół miliarda metrów sześciennych wody ma spłynąć rzeką do Kalifornii. Mieli pełno wody, po prostu nie wolno im było jej tknąć.

Utwory Bacigalupiego wpisują się $\mathrm{w}$ narrację o antropocenie, w ramach której mówi się o tym, że głównym czynnikiem kształtującym obecny okres geologiczny jest działalność człowieka ${ }^{10}$. Spalanie paliw kopalnych, przemysłowa hodowla zwierząt oraz masowa wycinka lasów to tylko niektóre z obszarów ludzkiej działalności napędzających zmiany klimatyczne. W tym kontekście przyszłość planety znajduje się całkowicie w rękach ludzkości. Bruno Latour mówi o nastaniu czasów postnaturalnych ${ }^{11}$. Posiłkując się koncepcją Gai opracowaną przez Jamesa Lovelocka, Latour dodaje do niej figurę Atlasa, symbolizującą współodpowiedzialną ludzkość. Takie podejście napotyka wiele wyzwań, między innymi problem rozproszenia owej odpowiedzialności. Zakłada ono także konieczność globalnej koordynacji działań. Bacigalupi umiejętnie rozpoznaje rozmycie podziału pomiędzy naturą a kulturą:

- Ekosystem się rozleciał, kiedy człowiek pierwszy raz przepłynął morze. Kiedy pierwszy raz rozpaliliśmy ogień na rozległej afrykańskiej sawannie. Potem tylko przyśpieszaliśmy to zjawisko. Łańcuch pokarmowy, o którym mówisz, to nostalgia i nic poza tym. [...] Natura to my. Całe to nasze majsterkowanie to natura, każde nasze biologiczne dążenie. Jesteśmy czym jesteśmy, a świat należy do nas. Jesteśmy jego bogami. A jedyny problem to to, że nie chcecie wypuścić na świat całego swojego potencjału ${ }^{12}$.

Dzieła Bacigalupiego realizują ścieżkę, którą można określić jako krytyczną wobec perspektywy antropocenowej. Wprowadza on do opisywanych światów element transhumanistyczny, problematyzując to, co oznacza termin 'człowiek' (anthropos). W przypadku Nakręcanej dziewczyny odbywa się to poprzez wprowadzenie postaci Emiko - Nowego Człowieka, genetycznie zmodyfikowanej istoty, której przeznaczeniem jest bezgraniczne posłuszeństwo. Zaprojektowana jako perfekcyjna towarzyszka, sekretarka, prostytutka, Emiko posiada idealnie gładka, pozbawioną porów skórę. Zostaje wrzucona do świata zdewastowanego jeszcze przed jej przybyciem. Jej istnienie można w serii pytań zwrócić przeciwko antropocenowej koncepcji homogenicznego człowieka: co to

9 Ibidem, s. 132.

10 P. J. Crutzen, Paul J., E. F. Stoermer, W. Steffen, The 'Anthropocene', w: The Future of Nature: Documents of Global Change, red. L. Robin, S. Sörlin, P. Warde, Yale University Press, New Haven 2000, s. 483-490.

11 B. Latour, Facing Gaia: Eight Lectures on the New Climatic Regime, Polity, Cambridge 2017.

12 P. Bacigalupi, Nakręcana dziewczyna. Pompa numer sześć i inne opowiadania, s. 474. 
znaczy „być człowiekiem”? Czy i w jaki sposób Emiko oraz jej podobni są odpowiedzialni za stan planety? Podobną krytykę można wysnuć z samej konstrukcji świata Nakręcanej dziewczyny, w którym ludzkie masy zmuszone są do walki o podstawowe środki do życia: $\mathrm{w}$ jaki sposób mieszkańcy Tajlandii z powieści odpowiadają za działania ponadnarodowych korporacji?

Bacigalupi celnie ujmuje zjawisko, które w naukach społecznych nosi miano „uchodźstwa klimatycznego":

Jak okiem sięgnąć, ludzie z żółtymi kartami: cały naród, który uciekł do potężnego Królestwa Tajów z Malezji, gdzie nagle stał się niemile widziany. Olbrzymia, skrzepła masa uchodźców, oddana pod władzę białych koszul Ministerstwa Ochrony Środowiska, jakby byli tylko kolejnym gatunkiem szkodników do opanowania, czymś jak cibiskoza, rdza pęcherzowa i genhakowane ryjkowce. Żółte karty, żółte twarze ${ }^{13}$.

Według badacza Haralda Welzera nasilające się wskutek zmian klimatycznych katastrofy, takie jak susze, huragany czy powodzie, zmieniają kształt stosunków społecznych w rejonach oddziaływania ${ }^{14}$. Prowadzą do zmiany map etycznych i uwidaczniają ukryte konflikty społeczne, które, eskalując, wytwarzają fale uciekinierów. Tym sposobem katastrofy klimatyczne przekształcają się w katastrofy społeczne: wybuchają wojny, dochodzi do ludobójstw, których efektem są ruchy migracyjne. Ich efektem jest pojawienie się niezwykle licznej kategorii tak zwanych ludzi-odpadów: jednostek strukturalnie wykluczonych, pozbawionych praw obywatelskich, niezdolnych do konsumpcji, problematycznych i niepożądanych z punktu widzenia władz i kapitału ${ }^{15}$.

\section{Bacigalupi a kontrowersje naukowo-techniczne}

Kwestia kontrowersji naukowo-technicznych pojawia się niemal we wszystkich opowiadaniach Pompy numer sześć. Andrzej W. Nowak zwraca uwagę na celność intuicji Bacigalupiego dotyczącej koncepcji krążenia wiedzy zawartej $\mathrm{w}$ tytułowym opowiadaniu tomu oraz problematyki etycznej związanej z postępem naukowo-technicznym, przedstawionej w opowiadaniu Paszo ${ }^{16}$. Akcja opowiadania Pompa numer sześć rozpoczyna się w momencie awarii jednej z ostatnich pomp, odprowadzających

13 Ibidem, s. 166.

14 H. Welzer, Wojny klimatyczne, przeł. M. Sutowski, Wydawnictwo Krytyki Politycznej, Warszawa 2010.

15 Z. Bauman, Życie na przemiat, przeł. T. Kunz, Wydawnictwo Literackie, Kraków 2004.

16 A. W. Nowak, Kiedy umrze ostatni inżynier, „RitaBaum” 2014, nr 33, s. 113-115. 
nieczystości z miasta. Nikt jednak nie wie, jak ją naprawić - firma, która ją zaprojektowała już dawno nie istnieje, a ze względu na postępującą umysłową degenerację ludzkości brakuje inżynierów, którzy mogliby pomóc. Główny bohater podejmuje jednak trud zdobycia wiedzy koniecznej do naprawienia uszkodzonej maszyny. Jest to ogromny wysiłek, który do tej pory wykonywany był kolektywnie, znacznie przekraczający możliwości pojedynczej osoby. Następuje zerwanie łańcucha przekazywania wiedzy, tymczasem, jak pisze Latour, technonauka istnieje dzięki dobremu stanowi torów, po których krąży, a to oznacza współpracę wielu aktorów, nie tylko naukowców czy inżynierów, ale także dziennikarzy czy publicystów ${ }^{17}$.

Przywrócenie względnej stabilności światu w Nakręcanej dziewczynie możliwe było dzięki innowacjom w pozyskiwaniu energii ze sprężyn oraz genetyce, której owocem były między innymi wysokoenergetyczne glony oraz gigantyczne słonie, megadonty. Modyfikacjami genetycznymi w świecie powieści zajmują się genhakerzy. Stanowią oni trzon technokratycznej struktury świata przyszłości. Takimi postaciami są Gi Bu Sen z Nakręcanej dziewczyny oraz Bowman, genhaker-renegat, z opowiadania Kaloriarz. Bacigalupi zwraca uwagę na wątpliwości etyczne związane z modyfikacjami genetycznymi. Jak daleko będą się w stanie posunąć korporacje zajmujące się produkcją żywności? W świecie Nakręcanej dziewczyny toczy się wojna pomiędzy naukowcami, którzy na zmianę kodują i dekodują geny roślin oraz zwierząt. Wynikiem ich działań są wspomniane wcześniej choroby, ale także uodporniona na nie żywność. Odpowiadają także za powstanie Nowych Ludzi.

Bacigalupi nie stroni od tematu nieśmiertelności. W opowiadaniu zatytułowanym Regulator opisuje on przekształcenie struktur społecznych w wyniku pojawienia się rejuwy - środka umożliwiającego regenerację komórek. Efektem ubocznym nieśmiertelności jest bezpłodność, jednak znajdują się ludzie, którzy odrzucają możliwość wiecznego życia, by móc się rozmnożyć. Nazywani są oni „wszarzami”. Jako niższa klasa społeczna żyją w zaciemnionych partiach miast. Eliminują ich regulatorzy, czyli specjalni agenci, pracujący dla nieśmiertelnych mieszkańców z wyższych sfer.

Problem nieśmiertelności dostrzegł Francis Fukuyama, stwierdzając, że będzie to jedna z tych kwestii, które najmocniej wpłyną na politykę w najbliższej przyszłości ${ }^{18}$. Już teraz wydłuża się życie społeczeństw, przy jednoczesnym starzeniu się ich. W tradycyjnie ujmowanych społeczeństwach wiek wyznaczał hierarchię - osoby sędziwe znajdowały się

17 B. Latour, Nadzieja Pandory, przeł. K. Abriszewski, Wydawnictwo Naukowe UMK, Toruń 2013.

18 F. Fukuyama, Koniec człowieka, przeł. B. Pietrzyk, Wydawnictwo Znak, Kraków 2004. 
w niej wyżej. Wynalezienie środka na nieśmiertelność może doprowadzić do całkowitego spłaszczenia tego wymiaru, co z jednej strony niesie obietnicę egalitaryzacji, ale z drugiej potencjalnie ograniczy dynamikę społeczną, zatrzymując innowację. Konieczne stanie się nieustanne podnoszenie kwalifikacji - pojawią się nowe formy aktywności, które dziś są poza zasięgiem człowieka. W Regulatorze Bacigalupiego pojawia się postać Alice, która dzięki możliwości nieograniczonego czasem trenowania potrafi zagrać na altówce nawet najtrudniejsze utwory. Jest w tej wizji pewien optymizm, jednak z całą pewnością nie da się przewidzieć wszystkich konsekwencji manipulowania żywą tkanką.

\section{Podsumowanie}

Umiejscowienie twórczości Paolo Bacigalupiego w kontekście wybranych elementów kapitalistycznego systemu-świata ujawnia jej krytyczny potencjał. Poprzez zastosowanie nośnych metafor, mających swoje odniesienia we współczesnym świecie, autor ten przybliża czytelnikom kwestie, które są albo w najbliższej przyszłości będą wyzwaniem dla globalnej społeczności, takie jak systemowa bifurkacja, zmiany klimatyczne, masowe migracje, czy przekształcenia relacji społecznych spowodowane wprowadzeniem elementów transhumanistycznych. Na szerszym gruncie badawczym rodzi to pytania o możliwe relacje pomiędzy kulturą popularną i naukami społecznymi, otwierając pole dla dalszych badań o interdyscyplinarnym charakterze.

\section{Bibliografia}

Bacigalupi P., Nakręcana dziewczyna. Pompa numer sześć i inne opowiadania, przeł. W. M. Próchniewicz, Wydawnictwo MAG, Warszawa 2011.

Bauman Z., Życie na przemiat, przeł. T. Kunz, Wydawnictwo Literackie, Kraków 2004.

Bello W., Wojny żywnościowe, przeł. P. M. Bartolik, Instytut Wydawniczy Książka i Prasa, Warszawa 2011.

Crutzen P. J., Stoermer E. F., Steffen W., The 'Anthropocene', w: The Future of Nature: Documents of Global Change, red. L. Robin, S. Sörlin, P. Warde, Yale University Press, New Haven 2000, s. 483-490.

Fukuyama F., Koniec człowieka, przeł. B. Pietrzyk, Wydawnictwo Znak, Kraków 2004.

Latour B., Facing Gaia: Eight Lectures on the New Climatic Regime, Polity, Cambridge 2017.

Latour B., Nadzieja Pandory, przeł. K. Abriszewski, Wydawnictwo Naukowe UMK, Toruń 2013. 
Nowak A. W., Kiedy umrze ostatni inżynier, „RitaBaum” 2014, nr 33, s. 113-115 .

Wallerstein I., Analiza systemów-światów. Wprowadzenie, przeł. K. Gawlicz i M. Starnawski, Wydawnictwo Akademickie Dialog, Warszawa 2007.

Wallerstein I., Koniec świata jaki znamy, przeł. M. Bilewicz, A. W. Jelonek, K. Tyszka, Wydawnictwo Naukowe Scholar, Warszawa 2004.

Wallerstein I., Nowoczesny system-świat, przeł. A. Ostolski, w: Współczesne teorie socjologiczne, red. A. Jasińska-Kania, L. Nijakowski, J. Szacki, M. Ziółkowski, Wydawnictwo Naukowe Scholar, Warszawa 2006.

Wallerstein I., Utopistyka. Alternatywy historyczne dla XXI wieku, przeł. I. Czyż, Oficyna Trojka, Poznań 2008.

Welzer H., Wojny klimatyczne, przeł. M. Sutowski, Wydawnictwo Krytyki Politycznej, Warszawa 2010.

Ziegler J., Imperium hańby, przeł. E. Cylwik, Instytut Wydawniczy Książka i Prasa, Warszawa 2011.

\section{Streszczenie}

Paolo Bacigalupi jest uznanym autorem science-fiction. Jego powieści i opowiadania dowodza, że jest twórcą o wyjątkowej wrażliwości społecznej. Niniejszy artykuł przedstawia możliwą interpretację jego prac, analizując je w kontekście wybranych zagadnień nauk społecznych. Poprzez porównanie elementów światów przedstawionych do współczesnych teorii staram się rozpoznać potencjał wyjaśniania świata w utworach Bacigalupiego. Artykuł rozpoczyna się od porównania świata Nakręcanej dziewczyny do elementów teorii systemów-światów Immanuela Wallersteina. Następnie podejmuję temat technokratycznej refeudalizacji i tego, jak jest ona przedstawiona w powieści. Powołuję się przy tym na takich autorów, jak Jean Ziegler i Walden Bello. Trzecia część rozprawia się z ekologicznymi aspektami opowieści autorstwa Bacigalupiego i prezentuje ich interpretację jako przedstawiających krytyczny punkt widzenia w debacie o antropocenie. Ostatnia część artykułu mówi krótko o niektórych kontrowersjach technonaukowych, obejmując kwestie reprodukcji wiedzy i etyczne aspekty inżynierii genetycznej przedstawione w Nakręcanej dziewczynie oraz w zbiorze opowiadań Pompa numer sześć. Według mnie prace Paolo Bacigalupiego, jako science-fiction, wykazują się nie tylko wartością rozrywkową dostarczając wiarygodnego, pozaakademickiego źródła krytycznego namysłu.

Słowa kluczowe: Bacigalupi, system-świat, Wallerstein, Latour, antropocen, zmiana klimatyczna, kapitalizm, uchodźca, refeudalizacja, technonauka 


\section{Summary}

\section{Windup Worlds. Paolo Bacigalupi's Works and Chosen Aspects of The Capitalist World-System}

Paolo Bacigalupi is a renowned science-fiction author. His novels and short stories prove that he as a writer shows an exceptional social sensitivity. This article presents a possible interpretation of his works made by inserting them into a context of social sciences. By comparing the elements of presented worlds to modern theories Iwill try to recognize the explanatory potential of Bacigalupi's fiction. The article begins with a comparison of The Windup Girl world to the elements of world-system theory by Immanuel Wallerstein. Next, I will move to the topic of technocratic refeudalization and how it is presented in the novel. Here I recall such authors as Walden Bello and Jean Ziegler. The third section deals with the ecological aspect of Bacigalupi's stories and the way it could be interpreted as a critical point of view in a debate on the anthropocene. The last section of this article deals shortly with some technoscientific controversies concerning the reproduction of knowledge and ethical aspects of genetic engineering, portrayed in The Windup Girl and Pump Number Six story tome. I will argue that Bacigalupi's works, as science-fiction, surpass their entertaining value delivering a convincing non-academic source of critical thought.

Keywords: Bacigalupi, world-system, Wallerstein, Latour, anthropocene, climate change, capitalism, refugee, refeudalization, technoscience 